CLINICAL HEMORHEOLOGY, Vo1. 8, pp. 287-291, 1988

$0271-5198 / 88 \$ 3.00+.00$ Printed in the USA.

Copyright (c) 1988 Pergamon Press plc. All rights reserved.

\title{
FIFTH EUROPEAN CONFERENCE ON CLINICAL HEMORHEOLOGY
}

\section{FAHRAEUS AWARD CEREMONY}

Laudatio: Fåhraeus Awardee Jean-François Stoltz

H. Schnid-Schönbein

M.F., Rhein.-Westf. Technische Hochschule, Aachen F.R.G.

It is my special pleasure and privilege to introduce to you at this time - the 1987 recipient of the FAHRAEUS Award, created to promote clinical haemorheology. After shu CHIEN, John DORMANDY and myself, Jean-François STOLTz is the fourth scientist, chosen in a complex two ballot procedure by his peers around the world.

Jean-Frangois STOLTZ was born in Clexmont-Ferrand on the 29th of April 1942, thus being the youngest recipient of the FÄHRAEUS AWARD. After finishing school he attended preparatory classes in the Grandes Ecoles d'Ingenieurs (Mathématiques supérieures et spéciales) and he gained admission to several ecoles superieures, chosing for his professional training from 1963 to 1966 "I'Ecolo Superieure des Mines et de la Metallurgie de Nancy" and gained his degree as "ingenieur civil des mines et de la metallurgie" in July 1966. It was during his subsequent military service from 1966 to 1968 that he made contact with problems concerning blood and therefore with biorheology, because he was commissioned to the scientific staff of the central transfusion service of the French national army at Clamart. Already before that time his Hife Maryse, a pharnacist, had worked with Professor inlain Larcan on the old familiar subject of blood sludging. She gained her doctorate in pharmacy in paris on this subject and Professor Larcan was on her examining board. The joint work of Maryse and Jean-Francois Stoltz and Alain Larcan was presented at the 1st International Conference of Hemorheology in Reykjavik in 1966.

Prof. Larcan had become aware of the great potential of the mathematical and physical knowledge and skills of his student's husband, and recommended Jean-Francois stoltz to Prof. Streiff after he had taken over a directorship of the Centre Régional de Transfusion Sanguine de Nancy. In 1969 Jean-Francois stoltz started a residency at the center where he himself now holds the position of a Director of Research. 
As everyone krows, Joan-Francojs storta is not a phyianar instead he qualified acadenically as a doctor in physical. chemistry, the title of his thesis was

"res phenonénes électrocinélines aux interfacer solides-liquides. Application a la suspension sanguine".

In 1971 he gained his doctorate in the physical soiendes with two theses, both including a haemorheological tomic

"L'Etude de la stabilité du sang et de certaines réactions immunohématologiques".

It will be no surprive for anyone to learn that he has been granted these degrees with great honours and expicit congratulations by the jury.

Jean-Frangois Stoltz's professional anor son became fimensiy diversified. Apart from his various duties as ar ryminonta? haemorheologist, he was put in cbarge of swoh time consuming technical chores as "plasma services", plasma fractionation, plasma lyophylisation, and the whole duta processing and research organization in the transfusion center. These activities did not prevent him from devoting most of his time and efforts to search for the unknown. Here, his brilliant scientific discoveries and developments and the leadership for many young scientists of all disciplines prove his success.

In recognition of his past merits and future services, he was gradually incorporated into different academic boards of the medical farulty at the university of Nancy. After baving been appointed Director of Research in 1983, in september 1935 he wass appointed as Professor of Hatratology by the Medical Faculty of the University of Nancy. This is a great achievement, indeed, one has to congratulate not only Jean Francois, but the faculty members for their foresight in adnitting him to their midst. By this decision the University acknowledged that Jean-Francois Stoltz had been made Director of the INSERM-Unit Nr. 284 on "advanced instrumentation" by the French government.

In all of France and around the world, Jean Francois stoltz is not just a well known and highly respected scientist, but also generally taken as a bona fide personifjcation of "sucessful interdiscipinary research". He is an active member ard executive officer in numerous national and international societies on hematology, microcirculation, transfusion and thrombosis. For the nascent community of clinical haemorheology, however, his most important single achievement was certainly his effort in organizing - together with Pierre Drouin - a meeting that was renamed retroactively as "1. European Conference on clinical 
Hemorheology". Pierre Drouin wrote to me that..."the idea of a symposion devoted to hemorheology and diseases appeared at the end of 1978 at a supper in Jean Francois's home and after a bottle of whisky". It was certainly not a bad idea or a "Schnaps"-Idee as we say in Germany. As we all remember, their plans met with immediate success and left a permanent trace. The "European Symposion" became the root of all later European conferences on Clinical Haemorheology. I remember quite vividly that an ad hoc committee of clinically oriented or clinical haemorheologists met over lunch at the last day of the meeting. agreed to have similar such meetings every two years, and even conspired in selecting the organizers for the 2 nd, 3 rd and the 4 th. It was further agreed that the meetings should alternate with the well established bi-annual series of conferences of the European Society for Microcirculation. The meeting in London, the one in Baden-Baden, the last one in siena and now this one in Bordeaux testify to the intensification, as well as to the extension of our new science. It is certainly no coincidence that - for all the merits of Leo Dintenfass in Australia, the large group of researchers in Japan and the untiring efforts of Shu Chien and Herb Meiselman in the USA, mostly European c 1 in $i c i$ a $n$ s have taken up research in clinical haemorheology. Everyone who understands the social structures underlying interdisciplinary research appreciates the immense significance of meetings where the novices - and we are all still in the early learning phase of our field - can meet and exchange ideas. By now virtually every discipline of medicine and surgery sends its representatives to our meetings and profits from the work of theoreticians and experimentalists like Jean-Francois stoltz.

It is a truism to state that clinical hemorheology will grow with the success of improving our methods for quantitative assessment of very complex, but vitally important "anomalous" flow phenomena. As I have pointed out earlier, many of our problems evade the paradigms and measurement devices, developed in the physical and chemical sciences. Fortuitously, many engineers are attracted by this field and many of them have made important contributions.

Jean - Francois stoltz is in all his mind and heart a "bridge-builder". The apparatus he designed, but also the many publications and textbooks he wrote (often in cooperation with physicians), have become standard sources of references. It is largely due to his efforts that a very broad spectrum of hemorheological thoughts are now pursued in almost every French university and in many municipal and regional hospitals.

Our friend Jean-Francois has one weakness: he is the proverbial "work-aholic". All my informants agree in stressing that he comes 
in early and works late, devoting even his weekends to his most essential scientific activities.

Usually, individuals become honoured by a prize. At times, a prize gets honoured by the recipient. As a young community of clinical haemorheologists in Europe, we acknowledge gratefully that the status of the FAHRAEUS Medal has been greately enhanced by the selection of Jean-Francois Stoltz, a mining engineer who has helped medicine and, therefore, mankind by this successful search for new knowledge and practical tools to combat disease.

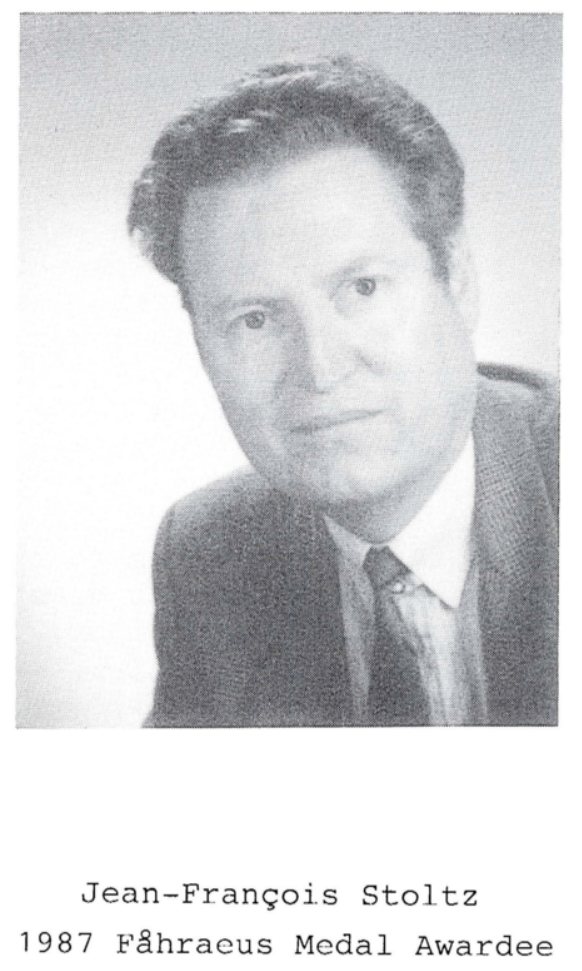


THE 1987 FAHRAEUS MEDAL AWARD

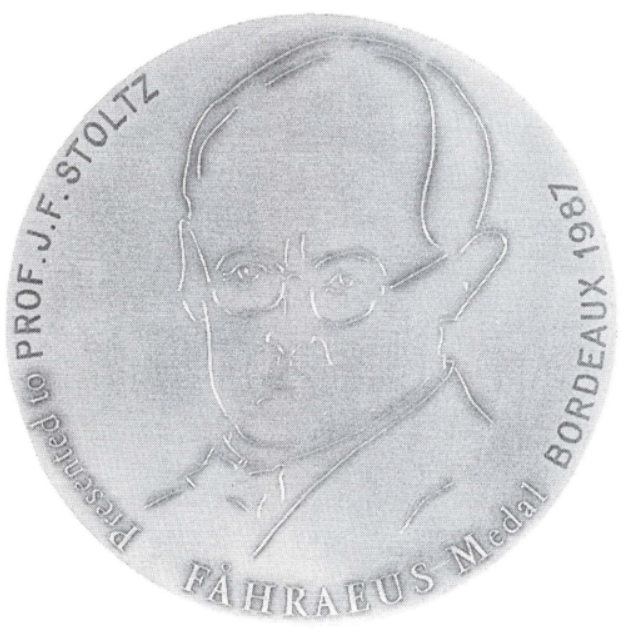

FIG. 1

Front side of Fahraeus Medal, designed by L. Alcopley

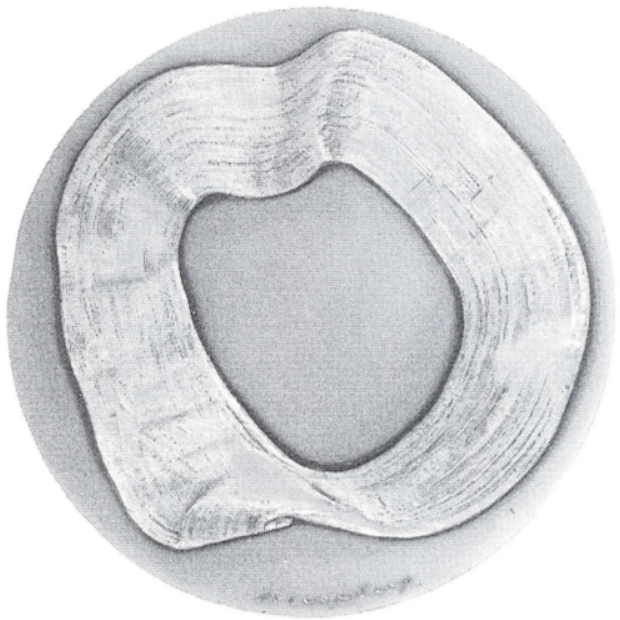

FIG. 2

Back side of Fåhraeus Medal, designed by L. Alcopley 